\title{
The Welfare Cost of Inflation
}

\author{
JOHN A. TATOM
}

0

NE of the most controversial and least understood concepts of economic theory is that of the "welfare cost" associated with fully anticipated inflation. Other costs or burdens of inflation receive considerable attention in the press, but the burdens usually discussed are those associated with unanticipated inflation. Moreover, most of the costs of inflation which are widely recognized and discussed involve transfers of income and wealth from one group to another. For society as a whole, the value of these losses, or costs to some, tend to be offset by the value of gains, or benefits, accruing to others. In contrast, little or no attention is focused on the net loss of valuable services which society bears due to inflation, or what economists call the welfare cost of inflation.

It is widely agreed that most of the costs of inflation can be eliminated by the creation of an environment where the inflation rate is stable or reasonably constant and the rate is correctly anticipated by parties to financial contracts. Indeed, it has been suggested that not only can the costs of inflation be eliminated, but some benefits of inflation may be preserved or enhanced by promoting a stable anticipated positive rate. This argument has been put forward by many analysts, especially by a group of economic development economists of the "structural" school. ${ }^{1}$ More re-

\footnotetext{
The leading proponent of this school is generally regarded to be Raul prebisch. A discussion of the inflation theory of this school may be found in Dudley Seers, "A Theory of Infiation and Growth in Under-developed Economies Based on the Experience of Latiz America, Oxford Economic Papers (June 1962), pp. 173-95; or Julio H. G. Olivera, "On Structural Inflation and Latin-American 'Structuralism', Oxford Economic Papers (Novenber 1964), pp. 321-32.
}

cently, such an argument has been developed by monetary economists in this country. The implication of such arguments is that a stabilization policy which ensures that existing inflation is fully and correctly anticipated is, at worst, a satisfactory substitute for a policy to eliminate inflation and at best, superior to the elimination of inflation.

An orthodox analysis of inflation suggests that there is a trade-off involved in anticipated inflation. According to this analysis, there is a revenue resulting from inflation which accrues to a government which controls the production of fiat money. This revenue provides greater purchasing power to the government, allowing it to increase government expenditures, or to reduce alternative sources of purchasing power, that is, other taxes. Moreover, when the rate of inflation is correctly anticipated, the capricious effects of inflation on the distribution of income and wealth do not occur.

But there is an "excess burden" of inflation, even if it is correctly anticipated. That is, a given rate of inticipated inflation will cost members of society more than the revenue which accrues to the government. The excess is called the excess burden, or "welfare cost" of inflation. Both the revenue and the welfare cost of inflation are positively related to the level of the rate of inflation. Therefore, the "best" rate of inflation must be chosen with reference to the revenuecost trade-off of inflation and the revenue potential and associated costs of alternative revenue sources.

The case supporting a stable perfectly anticipated positive rate of inflation is strengthened by arguments 
which assert that the welfare cost of inflation is very small. In some of these arguments, the size of the welfare cost of inflation is absolutely dismissed. A notable example is the Presidential Address of Professor James Tobin to the American Economics Association in December 1971. Discussing the relationship between unemployment and inflation, he said of the cost of inflation:

According to economic theory, the ultimate social cost of anticipated inflation is the wasteful use of resources to ecotomize holdings of currency and other noninterest-bearing means of payment. I suspect that intelligent laymen would be utterly astounded if they realized that this is the great evil economists are talking about. They have imagined a much more devastating cataclysn, with Vesuvius vengefully punishing the simers below. Extra trips between savings banks and commercial banks? What an anti-climax!"

Other important examples may be found in the litera" ture on public finance. One of the best treatments of the welfare cost of taxation is that of Richard A. and Peggy B. Musgrave in their book, Public Finance in Theory and Practice. However, their work contains no discussion of the welfare cost of anticipated inflation. Moreover, they do emphasize the revenue from inflation."

This article is intended to serve two purposes. The first purpose is to explain the welfare cost of anticipated inflation. It is shown that this cost is not negligible. Thus, it is not a matter of indifference whether a government follows a policy of pursuing a very high or a very low rate of fully anticipated inflation. The second purpose is to show that, on the grounds of efficient taxation alone, the optimal rate of anticipated inflation and its revenue potential are not large. On rather generous assumptions favoring infationary finance, it is demonstrated that tax efficiency does not justify a positive rate of inflation.

The concern here is the cost associated with a constant and correctly anticipated inflation rate. The costs of unanticipated inflation which impact on parties to transactions in credit or resource markets, fixed income recipients, and taxpayers in general are ig-

ZJanes Tobin, "Inflation and Unemployment," The American Economio Review (March 1972), p. 15.

3Richard A Muserave and Peggy B. Musgrave, Public Finance in Theory and Practice (New York: MeGraw-Hill Book Company, 1973), p. 526 in footnote 11 , they dismiss the notion of a welfare cost of inflation by arguing that, as presented by some theorists recently, it is "a rather quaint basis on which to assess the case against inflation." nored.* These costs are substantial; indeed, they dwarf the cost addressed here. Nonetheless, it is theoretically conceivable that these costs may be avoided in an inflationary environment if inflation is correctly anticipated.

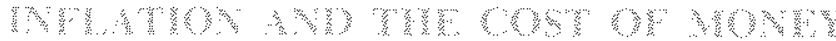

The seminal article on the welfare cost of inflation is Martin J. Bailey's 1956 article "The Welfare Cost of Inflationary Finance." ${ }^{3}$ He examined the cost of perfectly anticipated inflation to holders of real money balances in a stationary economy and illustrated those costs using data from several famous hyperinflations in various countries. Bailey also identified the revenue from inflationary money creation which accrues to a government which produces fiat money. This revenue is a transfer from money owners to all households through the government. Therefore, he argued that the social cost or excess burden of an inflation tax is the total cost to money owners less the transfer to government. Bailey's analysis is almost identical to the analysis of the welfare cost of an excise tax. ${ }^{6}$

A considerable literature has developed following Bailey's cost analysis. The focus of this literature has been on the implications of analyses such as Bailey's for an "optimum" rate of money growth and inflation. The primary extensions of Bailey's work have been accounting for growth of real output and for some technical considerations such as measurement, different expectation formation processes and the stability of an inflationary economy. Here we are interested in an exposition of the analysis of the cost of inflation and so a rigorous treatment of the development of the

The costs of unanticipated inflation are treated in most introductory textbooks. An excellent and brief discussion may also be fotind in J. Huston McCulloch, Money and Inflation: A Monetarist Approach (New York: Academic Press, 1975). See also Hans $\mathrm{H}$. Helbling and James E. Turley, "A Primer on Inflation: Its Conception, Its Costs, Its Consequences," this Retiew (January 1975), Dp. 2-8; Albert E. Burger, "The Effects of Infation (1960 68), this Review (November 1969), pp. 25-36; Michael R. Darby "The Financial and Tax Effects of Monetary Policy on Interest Rates," Economic Iriquiry (Jume 1975), pp. 271-73; and Jai-Hoon Yang, "The Case For and Against Indexation: An Attenpt at Perspective," this Review (October 1974), pp. 2-11.

5Martin 1. Bailey, "The Welfare Cost of Intlationary Finance", The Jounal of Political Economy (April 1956), pp. 93-110.

"See the screen insert, "The Welfare Cost of An Excise Tax." The methodology and theory underlying the concept of a welfare cost and its measurement here and in the discussion of the excise tax follow Arnold C. Hatberger. "Three Basie Postellates for Applied Welfare Econonics: An Interpretive Essay," The Journal of Economic Literafure (September 1971 ) pp. 785-97; and John C. Hanse, "The Theory of Welfare Cost Measnement," Joumal of Political Economy (December 1975), pp. 1145-82. 
literature is not pursued. Instead an attempt is made to present a "state of the arts" analysis drawing generously upon this literature.

Suppose that the economy is initially in equilibrium and there is no inflation. The purchasing power of the stock of money is exactly that which households demand. This situation is represented in Figure I. The demand for real money balances, a nominal stock of money deflated by the price level, is represented by D. The demand for real money balances is determined by the level of real income, real wealth, and the cost of holding real or financial assets. ${ }^{7}$ In Figure $\mathrm{L}$, the demand for real money balances is shown to be inversely related to the level of market interest rates represented by "the" interest rate, i. Other factors affecting the demand for money are held constant along $D$. The supply of real money balances is the dollar value of the existing stock of money (M) dellated by the general level of prices of goods and services, the equilibrium price level $\left(P_{0}\right)$. The existing stock of money is assumed to have been produced by a central bank acting as an agent of the government. No interest is paid on money in this analysis. The quantity of money can be changed through central bank purchases and sales of financial assets, in particular, by buying and selling government bonds. It is assumed below that each government bond has a principal amount equal to one dollar and pays the nominal rate of interest $i$, Given the initial levels of the other determinants of the demand for money, the equilibrium level of the rate of interest is $i_{0 .}$. Since there is no expected inflation initially, this rate of interest will be the same as the real rate of return ( $r$ ) on capital, or weal assets.

The price level depends on all factors determining the demand and supply of goods and services. In a stationary economy the price level depends primarily on the quantity of money. ${ }^{8}$ With unchanged preferences of all spending units, the general level of prices will be steady, if the quantity of money is constant. The actual rate of inflation will be the rate necessary to insure that real balances and the level of other real variables are equal to their equilibrium levels.

If the nominal stock of money grows at rate $\rho$ instead of zero, money holders will attempt to spend the

\footnotetext{
'An excellent discussion of the demand for moray may be found in Milton Friedman, "The Quantity Theory of Money m.m A Restatement," in Studies in the Quantity Theory of Money (Chicago: The University of Chicago Press, 1956), pp. 3-21.

A stationary economy is characterized by an absence of growth of resources or aggregate real income.
}

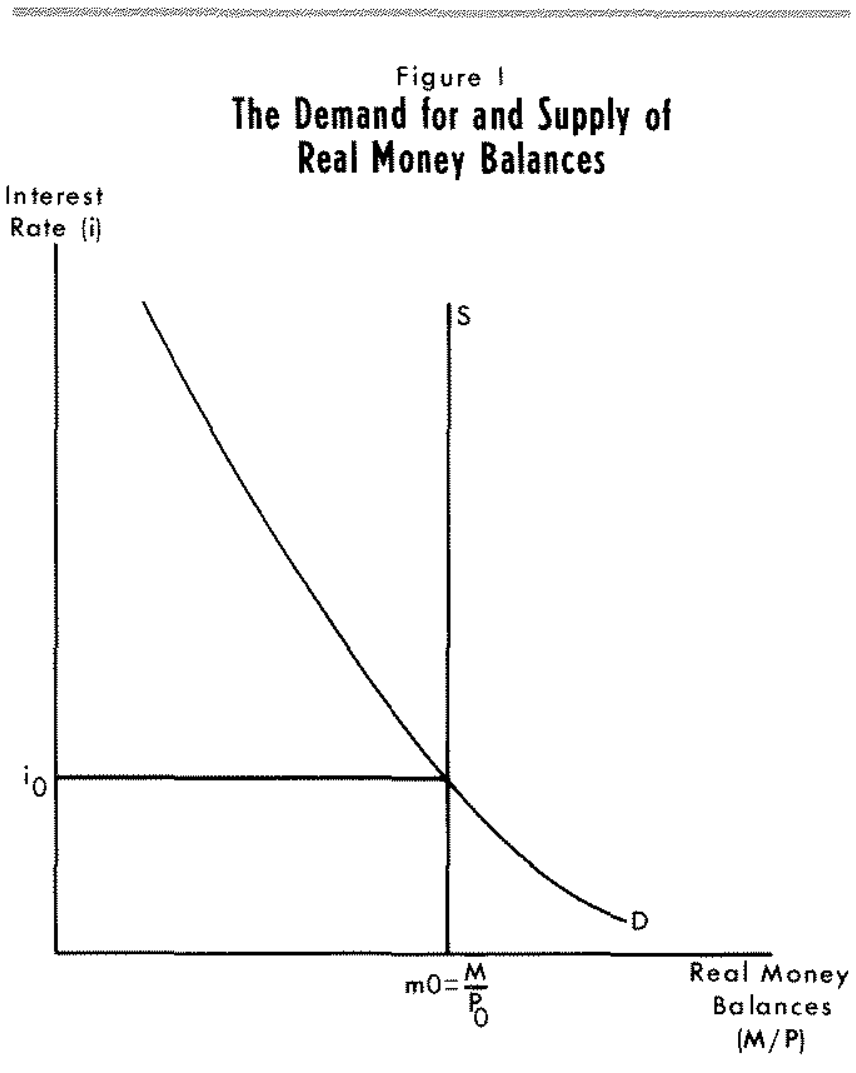

excess cash on goods and other assets in order to maintain the purchasing power of their initial money balances. Because of the increased demand for goods and assets, all dollar prices begin rising. The price level will rise at rate $\rho$ to eliminate a continuing excess supply of cash and excess demand for goods and other assets. After adjustment to the increase in the rate of monetary expansion from zero to $\rho$, the actual and anticipated rate of inflation, $\pi$, will equal $\rho$.

Inflation is a tax on real money balances because it raises the cost of holding a constant dollar of purchasing power. Since the nominal rate of interest rises to compensate lenders for the erosion of wealth which inflation would otherwise cause, the cost of holding a real dollar rises. An altemative way of viewing this cost is that owners of money must increase their holdings of dollars at the same rate as inflation in order to maintain the purchasing power of their cash balances. For each dollar held, the anticipated rate of inflation represents a cost of maintaining the purchasing power of the dollar, in addition to the real return which could have been earned on real assets.

The effects of a positive rate of monetary expansion and actual and expected inflation at rate $\pi$ can be seen in Figure II. The initial equilibrium, in the 


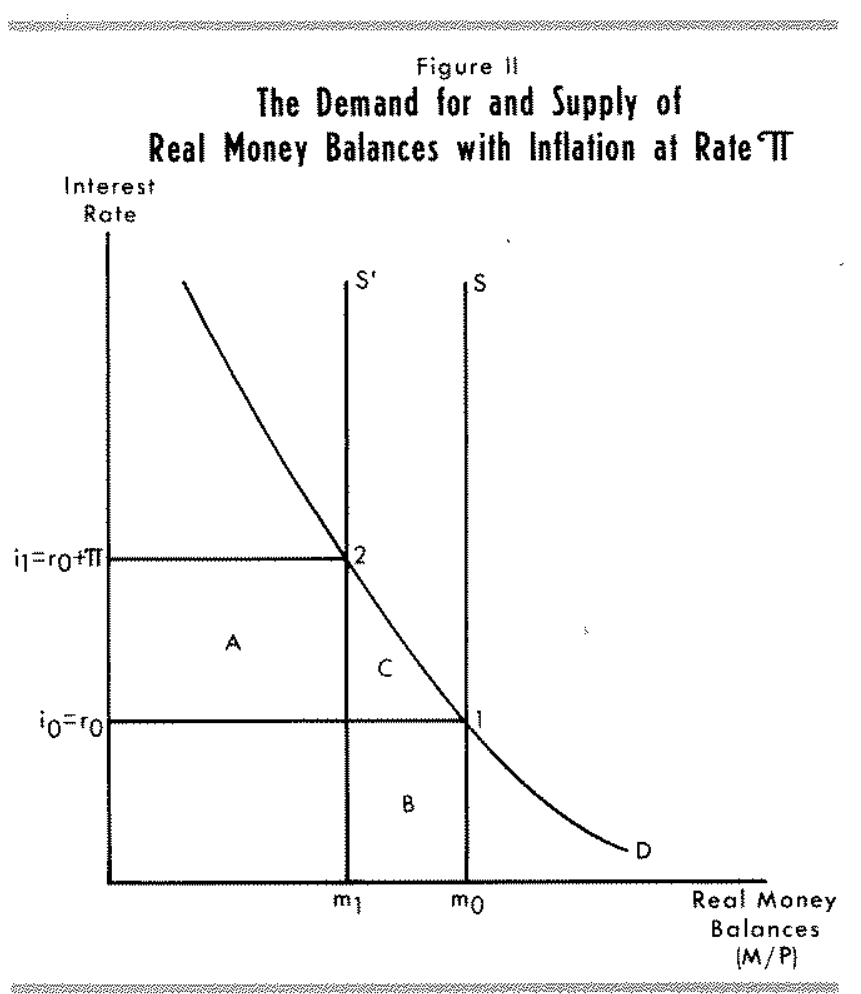

absence of inflation, is indicated at point 1 . The anticipation of inflation at rate $\pi$ will raise the cost of holding real balances to $\left(r_{n}+\pi\right)$, given the real rate of interest. Households will reduce their demand for real money balances to $m_{1}$, substituting other goods and assets for the relatively more expensive services of money. Given the other determinants of the demand for money, equilibrium is restored at point 2 . The growth in the nominal money supply will be matched by the rate of inflation so as to maintain the purchasing power of money balances at the level indicated by $\mathrm{m}_{1}$.

The total cost of perfectly anticipated inflation to owners of money is indicated in Figure II by the area $(\mathrm{A}+\mathrm{B}+\mathrm{C})$. Area $\mathrm{A}$ is the increased cost of holding $\mathrm{m}_{1}$ units of real money balances. Money holders pay a cost of $i_{1}$ per period per dollar of real cash balances, instead of io. This additional cost is a maintenance cost. It measures the real value of goods and services foregone to add nominal money balances at rate $\pi$. The total maintenance cost is this cost per unit of real money balances, $\pi$, times the level of real money balances, $\mathbf{m}_{1}$.

The second component of the total cost, the area $\mathrm{B}+\mathrm{C}$, is the real value of the services of money which is given up by money owners due to inflation. The demand price, $i$, at each level of real balances indicates the value of a unit of real balances per period.
For each unit of real balances given up by money owners, the value of the foregone services is measured by the corresponding interest rate along the demand curve.

The revenue from the tax on real money balances accrues to the government through the central bank. The revenue is reflected in the higher interest payments on the growing amount of bonds held by the central bank. This revenue is the area A in Figure II.

The revenue per period to the central bank is equivalently the real value of the continuous increase in its nominal money output $\left(\frac{1}{\mathrm{P}} \frac{\mathrm{dM}}{\mathrm{dt}}\right)$. Since the rate of monetary expansion $\left(\frac{1}{M} \frac{d M}{d t}=\rho\right)$ equals the rate of inflation $(\pi)$, the revenue per period $\left(\frac{1}{\mathrm{P}} \frac{\mathrm{dM}}{\mathrm{dt}}\right)$ is equal to the level of real money balances times the rate of inflation $\left(\frac{M}{P} p=m_{1} \pi\right)$. The added revenue of the central bank accrues to all households through the government so the area $\mathrm{A}$ is not a net cost. Instead, it is a transfer from money holders to all households. Therefore, the net cost to all households is the area $(\mathrm{B}+\mathrm{C})$.

Area $(B+C)$ is the excess of the costs to money holders over the benefits of inflation at rate $\pi$. It is the excess burden or welfare cost of inflation. Bailey and others have illustrated this cost. During periods of inflation (especially hyperinflation), payments procedures and habits change to avoid the capital losses which inflation imposes upon cash holding. ${ }^{9}$

However, it should be noted that the efforts to economize on money balances cited as illustrations of the excess burden of inflation are not necessary to the analysis which identifies area $(B+C)$ as the welfare cost. The identification of area $(\mathrm{B}+\mathrm{C})$ as the welfare cost implicitly assumes that the adjustment to perfectly anticipated inflation requires no use of resources. The adjustment has no direct cost, in the sense that scarce resources are diverted from the production of other real goods and services in order to economize on money holdings. Changes in the pay-

\footnotetext{
"See Bailey, "The Welfare Cost," pp. 96-102, More detailed descriptions of the changes in the payments process during rampant and expected inflation have been written by Frank D. Graham, Exchange, Prices, And Production In HuperInflation: Germany, 1920-1923 (New York: Ressell \& Russell, 1930); and Constantino Bresciani-Turroni, The Economics of Inflation (London: G. Allen \& Unwin, Ltd., 1937).
} 
ments process and habits are costless in Bailey's analysis.

The area $(B+C)$ is a measure of the lost value of the services of real money balances per period to all households. If the attempt to economize on real money balances due to inflation uses resources, the output of final goods and services available to house holds will be reduced and there will be additional deadweight losses to society. These additional adjustments are associated with the recession or depression which many believe must accompany continuous inflation, even a prolonged steady rate inflation, and which have been observed with prolonged periods of hyperinflation. ${ }^{10}$

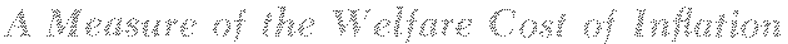

The size of the welfare cost of inflation, area $(B+C)$ is the area of a triangle $(C)$ and a rectangle (B). The area of the triangle is one-half the base, the reduction in real balances, times the height, the actual and expected rate of inflation. The area of $B$ is the same base times the height, the real rate of interest. Using the concept of elasticity, a general measure of the welfare cost may be written as:

$$
\text { W. C. }=\mathrm{e}^{*}\left(\frac{\mathrm{m}_{0}}{\mathrm{i}_{0}}\right) \pi(\pi / 2+\mathrm{r})
$$

where $e^{*}$ is the elasticity of demand for real money balances with respect to the nominal interest rate, given the real rate of interest $r_{0}{ }^{11}$ The welfare cost of inflation is directly proportional to the elasticity of demand and the level of real money balances which would prevail in the absence of inflation or deflation. The welfare cost of inflation is inversely related to the real rate of return on capital in an economy. The welfare cost increases at an increasing rate with the inflation rate.

A rough estimate of the size of the welfare cost of inflation can be made using existing empirical research on the demand for money. Most estimates of the interest rate elasticity of demand for money (defined positively) indicate that it is about .15. That is,

${ }^{10}$ Since this article concerns the cost of a sustained and correctly anticipated "pure" inflation, such arguments are outside the seope of the analysis here and will be ignored.

${ }^{11}$ The elasticity may be written symbolically as $\left(-\frac{\mathrm{dm}}{\mathrm{di}} \cdot \frac{\mathrm{i}}{\mathrm{m}}\right)$ so that $\mathrm{e}^{*}\left(\frac{\mathrm{m}}{\mathrm{i}}\right)$ is the reduction in real money balances per unit increase in the expected rate of inflation. The total reduction in real balances is this amount times the level of the expected rate of inflation. a one percent rise in the interest rate (for example, from 5 percent to 5.05 percent) will result in a .15 percent reduction in the demand for money. ${ }^{12}$

The level of real money balances (measured in current prices) which would exist in the absence of inflation, and the level of the real rate of return to capital are more difficult to determine. A level of 5 percent for the real rate of return is, if anything, a high estimate. An alternative estimate, which is illustrative is a 2 percent real rate. ${ }^{13}$ The $U$. S. money supply is about $\$ 300$ billion. Most observers believe that the rate of inflation to be expected, in the near term, is about 5 percent.

Other things being equal, the percentage increase in the nominal rate of interest due to a 5 percent expected rate of inflation as compared to no inflation is 100 percent if the real rate is 5 percent, and 250 percent if the real rate is 2 percent. For a real rate of 5 percent, one could expect mo to be 15 percent (.15 $\times 100$ percent) higher than the present level, or about $\$ 345$ billion. Alternatively, a 2 percent real rate implies a level of real balances 37.5 percent larger than at present, or $\$ 412.5$ billion.

These estimates imply a range of the welfare cost of inflation in equation ( 1 ) of $\$\left(52 \pi+517 \pi^{2}\right)$ billion to $\$\left(62 \pi+1547 \pi^{2}\right)$ billion. For an expected rate of inflation of 10 percent per year, the welfare cost would be $\$ 10$ to $\$ 22$ billion per year measured in current dollars. Alternatively, a 5 percent rate of anticipated inflation involves a welfare cost of $\$ 4$ billion to $\$ 7$ billion per year. These estimates give a rough measure of the order of magnitude of the welfare cost of inflation.

Welfare costs of various parts of the U. S. tax system have been estimated. To provide some comparisons, a few of the early estimates are cited here. While the state of the art in some areas is crude, these estimates provide useful approximations of the order

\footnotetext{
IESee the survey of a literature by David E. W. Laidler, The Demand for Money: Theories and Evidence (Scranton, Penusylvania: International Textbook Company, 1969), Chapter 8 . To the extent that .15 is too low, the welfare cost estimates given below understate the welfare cost of inflation. Milton Friedman has suggested that the 15 estimate may be too low. See Milton Friedman, The Optimum Quantity of Money and Other Essays (Chicago: Aldine Publishing Compary, 1969 ), p. 143 .

13 Milton Friedman, "Government Revente from Inflation," Joumal of Political Economy (July/August 1971), p. 852 and p. 854 , has suggested that a real rate of interest about equal to the rate of growth of real per capita income has "some basis in experience and theory." This sate of growth for the United States is about 2 percent.
} 


\section{THE WELFARE CO\&}

The analysis of the welfare cost of a tax is part of the overall theory of the effect of taxation. Most an alysts of the cost of inflation argue by analogy that inflation is a tax on the purchasing power of money or real cash balances. To understand fiflation as a tax it is necessary to review the analysis of the effect of taxation of another good, such as an excise tax on tobacco, alcohol, or long-distance phone calls.

In the accompanying Figure, the demand (D) for a product $\mathrm{X}$ is shown. The demand for $\mathrm{X}$ depends upon the price of the product. Of course, the demand depends on other characteristics of the economic enviromment of all potential purchasers of product $X$. The most important of these other determinants are the prices of closely related goods such as complement or substitute goods, the preferences of households, the real income of households, and its distribution. These other factors are assumed to be fixed in the Figure. Suppose that prodict $X$, in the absence of a tax, can be produced and sold at a current cost of $\$ 1 /$ unit of $X$, given technology and the value of resources necessary to produce a init of $X$. This is indicated by the supply curve in the Figure labeled $S$. In the absence of a tax, competition among producers insures that the market price will be $\$ 1 /$ unit and the amount purchased and sold will be the amount households demand, for example, 1 million units in the Figure.

Now suppose the government levies a tax on product $X$ of $\$ 1$ /unit or 100 percent. The cost of producing and selling the prodnct will rise to include the cost of the tax. The market price will rise to $\$ 2$ /unit of $X$. Households will not continue to buy as much of the product. Instead, they will substitute, buying other goods which have not changed in price. In the Figure, the demand for $\mathrm{X}$ falls to 8 million units per period of time.

The burden, or cost, of the tax to households is composed of three parts. First, households pay move for the units they continue to buy. Second, households forego the benefits of consuming the units which they no longer purchase each period $(200,000)$. The demand price at a given quantity indicates the value of a unit of $\mathrm{X}$ to households. Therefore, consumers lose a value of $X$ indicated by the area under the demand curve from .8 million units to 1 million units. Finally, households gain the benefits of more of other products as resources move from the production of $\mathrm{X}$ to the pro-

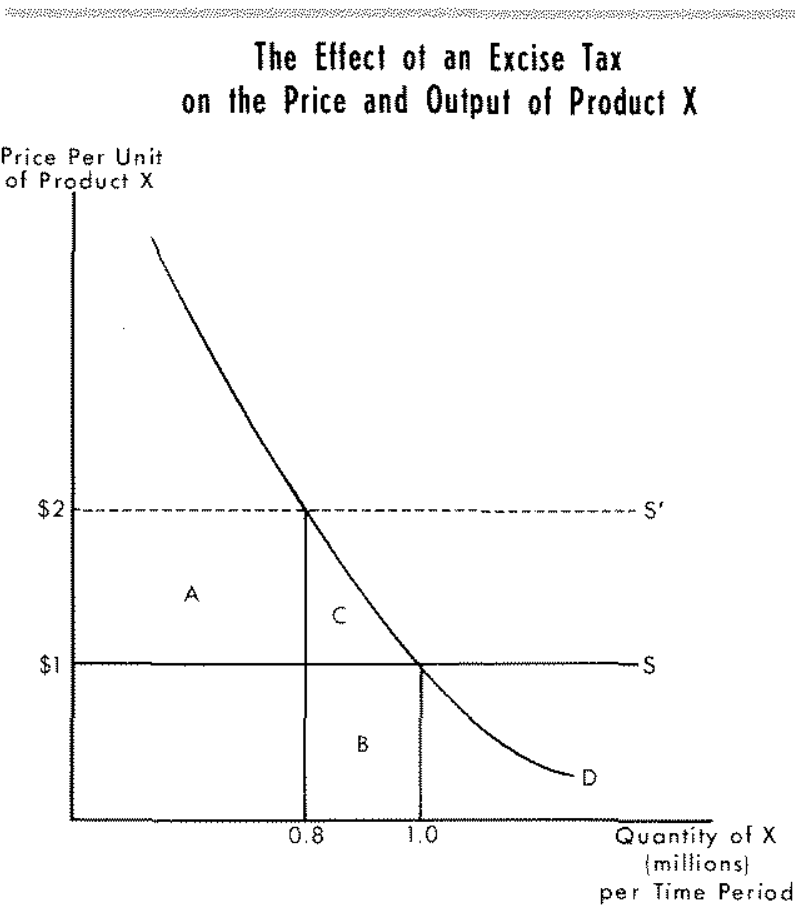

duction of these other goods. The supply price in dicated by curve $S$ measures the cost of resources needed to produce a unit of $X$. That cost is the maximum value of these resonrces in producing other goods for households. Therefore, the value of the additional other goods which households obtain is the area under $\mathrm{S}$ from 1 million units of $\mathrm{X}$ to .8 million units of $\mathrm{X} .^{1}$

The cost of the tax to households, in this example, is $\$ 900,000$. The first component, the additional cost of the units households continue to purchase, is $\$ 800,000$. This is the area of rectangle $A$ in the Figure. The second part of the cost, the value of $X$ which households lose is $\$ 300,000$. This is the area of the rectangle $B$ $(\$ 200,000)$ and the triangle $C(\$ 100,000)$. The third part of the costs the gain in the value of alternative products is the area of the rectangle $B(-\$ 200,000)$.

\footnotetext{
${ }^{1}$ In the case of fiat money the thind aspect here is absent. No resources are free to move into the production of other goods.
} 


\section{F AN EXCISE TAX}

The second and third part of the cost can be combined to obtain the net cost to households of the shift in the allocation of resources. This cost is $\$ 100,000$ in the example, the area of triangle $C$. It measures the cost to households of the distottion of their consumption patterns resulting from the tax. Society can produce 1 million units of $\mathrm{X}$ and less of other goods or .8 million units of $X$ and more of other goods. In the absence of the tax consumers would prefer the output mix with 1 million units of $X$ to that with .8 million unts. The value of the prefered mix over its altemative is the $\$ 100,000$ measired by triangle $C$. The total cost to purchasers of $X$ may be stated as the sum of areas $A$ and $C$. It includes the value of product which houseliolds must forego to pay the tax (A) and the net value of the product $X$ which households forego due to the tax.

The proceeds of revente from the tax is the tax/unit times the number of units which households continue to buy. In the example, this is the area of rectangle $A$. The proceeds of the tax are not truly a cost to households. In fact, the proceeds will be spent on goods or transferred back to households. The tax reventue does not affect the capacity of the economy to prodtce goods and services. The value of the foregone product for households, measured by rectangle $A$, is the value of the product which govemment either purchases for all households or permits households to continue to purchase through a transfer of the tax revenue back to them. Rectangle A is not a cost to society. It is merely a financial transfer within the economy. Area $\mathrm{C}$, the triangle, is the only remaining cost of the excise tax.

The analysis of the cost and benefits of a tax may be summarized as follows. The tax imposes costs on household purchases of the taxed good. The cost is measured by areas such as $(\mathrm{A}+\mathrm{C})$. The government receives proceeds of the tax equal to an area such as $A$. This benefit of the tax accues to all or some members of society. The cost of the tax exceeds the benefit of the tax by an area such as $C$. The excess is called an "excess burden" or the "welfare cost" of the tax on $X$. It measures the net loss to all households due to the distortion of resounce allocation caused by the interference in the market for product $X$. In the example, the welfare cost is $\$ 100,000$ per period.

A general measure of the welfare cost of an excise tax may be developed from the concept of the price elasticity of demand. This elasticity is a measure of the responsiveness of the quantity of a product which households demand, to changes in the price of the product. It may be defined as:

(1) $e=\frac{\text { percentage change in quantity of } X \text { demanded }}{\text { percentage ehange in the price of } X}$

The elasticity measures the percentage reduction in the quantity which households demand for each one percent rise in the price of product $X$.

The size of the welfare cost, approximately the area of a triangle such as $C$, is one-half the product of the size of the reduction in demand and the size of the increase in price. The size of the reduction in demand is related to the rise in price through the elasticity of demand. The welfare cost of a tax can be written as:

$$
\text { W. C. }=1 / 2 \text { e }\left(P_{0} X_{\theta}\right) t^{2}
$$

where $t$ is the percentage rate of the tax, the tax/unit divided by the original price. ${ }^{2}$ In the example, the elasticity of demand is 2 , the total expenditure on the good $\left(\mathrm{P}_{0} \mathrm{X}_{0}\right)$ is one million dollars per year, and the tax is $100 \%$. Thus, the welfare cost is $\$ 100,000 \mathrm{per}$ period.

In equation (2), the welfare cost of a tax is shown to be an increasing function of the elasticity of demand. The welfare cost of a tax increases with the square of the tax level, and is proportional to the size of the original tax base.

Equation (2) is not the most general measure of the welfare cost of a tax. There are other considera tions, such as the level of existing taxes on other goods and services and the technical or market conditions determining supply, which affect the measurement of welfare cost, However, the treatment of this simple case is sufficiently general for the discussion of money and inflation.

\footnotetext{
-Sinilar equations may be found in Amold $C$. Harberger "Taxation, Resource Allocation, and Welfare," Taxation and Welfare (Boston: Little, Brown and Compary, 1974), p. 34; and Richard A. Musgrave and Peggy B. Musgrave, Public Finance in Theory and Practice (New York: McGraw-Hill Book Company, 1973), p. 456.
} 
of magnitude of the costs. The major tax in the United States is the personal income tax. It distorts the choice between labor and leisure, encouraging longer vacations, greater absenteeism, early retirement and other means of reduced effort. The welfare cost of this tax has been estimated for 1961 to be one billion dollars per year. If the welfare cost per dollar of revenue were the same in 1975 as in 1961 , the welfare cost in 1975 would be about $\$ 3$ billion. Accounting for the substantial increases in the marginal tax rate since 1961 would dramatically raise this estimate. ${ }^{14}$ Musgrave and Musgrave have placed the order of magnitude of the welfare cost of selective sales and excise taxes at $\$ 3$ to $\$ 4$ billion per year for 1970 and that of the corporate income tax at about $\$ 1$ billion per year. ${ }^{15}$ The welfare cost of five percent anticipated inflation exceeds the welfare cost of the corporate income tax and it may be as large as that of the personal income tax.

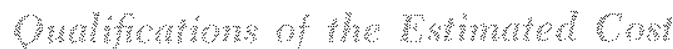

There are two problems with the cost measures which must be pointed out. First, they rely on an estimate of the elasticity of demand for money with respect to the anticipated inflation rate which may be a serious underestimate of that elasticity. ${ }^{16}$ Second, the measure in equation (1) is for an economy with zero growth of real output, not for a growing economy such as the United States.

The relevant elasticity of demand for money is the elasticity of demand with respect to the anticipated rate of inflation. This elasticity will only be related to the interest rate elasticity if, during the period when the interest elasticity is estimated, movements of the interest rate reflect only changes in inflation expectations and not changes in the real rate of retum on capital. There is a substantial volume of literature which argues that the demand for money is not very sensitive to changes in real rates of return on capital, while it is sensitive to changes in the anticipated rate of inflation. A given change in market interest rates which reflects a change in inflation expectations

\footnotetext{
14See Arnold C. Harberger, "Taxation, Resource Allocation, and Welfare," Tatation and Welfare (Boston: Little, Brown and Company, 1974), p. 47.

15 See Musgrave and Musgrave, Public Finance, pp. 458-59.

teRobert Barro implicitly uses an estimate of this elasticity of one half, Accordingly, his estimate implies a welfare cost of inflation move than three times the size given here. See Robert I. Barro. "Inflationary Finatnce and the Welfare Cost of Inflation" Joumal of Poltical Economy (September/ October 1972), pis. $978-1001$.
}

should have a sizeable impact on the demand for money vis-a-vis the demand for real and other financial assets. On the other hand, a given change in the market rate due to fluctuations in the real rate of return on capital will affect household consumptionsaving choices with little impact on the composition of desired asset portfolios, in particular, the demand for money. To the extent that observed interest rate changes have been due to changes in the real rate, the estimate of the interest elasticity understates the elasticity of demand for real money balances with respect to the expected rate of inflation. ${ }^{17}$ Consequently, the true welfare cost measure would be higher than these estimates.

The second problem with the analysis above is that it ignores the effect of economic growth on the welfare cost of inflation. It has been suggested that the welfare cost of inflation is smaller in a growing society. ${ }^{18}$ If this suggestion is correct, the estimate of the annual cost of perfectly anticipated inflation is too large.

To assess the effect of growth on the welfare cost, consider Figure III. Growth increases the demand for real money balances from $\mathrm{D}$ to $\mathrm{D}^{\prime}$. The process of growth is continuous but it is sufficient to look at the discrete shift from one period to the next. For the same rate of anticipated inflation, $\pi$, the percentage increase in the quantity demanded of real balances is equal to the "income elasticity of demand" times the rate of growth of income. Since the demand for money at each point along $D$ increases by the same percentage, the demand at points 1 and 2 grows by that percentage, in one period of time, to points $I^{\prime}$ and $2^{\prime}$. The demand for real money balances at the smaller level, 2, grows by a smaller absolute amount than at the higher level 1 . The base of the triangle $C^{\prime}$ and of rectangle $B^{\prime}$ is larger than in $C$ and $B$ by the percentage growth in demand. For the same rate of

\footnotetext{
$17 \mathrm{~A}$ classic discussion of the propositions concerning the dem mand for money may be found in Friedman, "The Ouantity Theory," of "Interest Rates and the Deruand for Money." Both nay be found in Friodman. The Optimum Quantity as Chapter 2 and Chapter 7 , respectively. An example of a more rigerous derivation for an inventory theoretic demand model may be found in Edi Karni, "The Valtue of Time and the Demand for Money," Jotirnal of Money, Credit and Banking (February 1974), pp. 45-64. Considerable confusion continues to exist over the difference between these two elasticities. For an example, see Edmund $S$. Phelps, "Inflation in the Theory of Ptblic Finance" The Stuedish Joumal of Economics (March 1973), pp. 67-82, especially p. 76 and p. 82

18 See Chartes D. Cathcart, "Monetary Dynamics, Growth, and the Efficiency of Inflationary Finance," Journal of Money, Credit and Banking (May 1974), p. 189.
} 


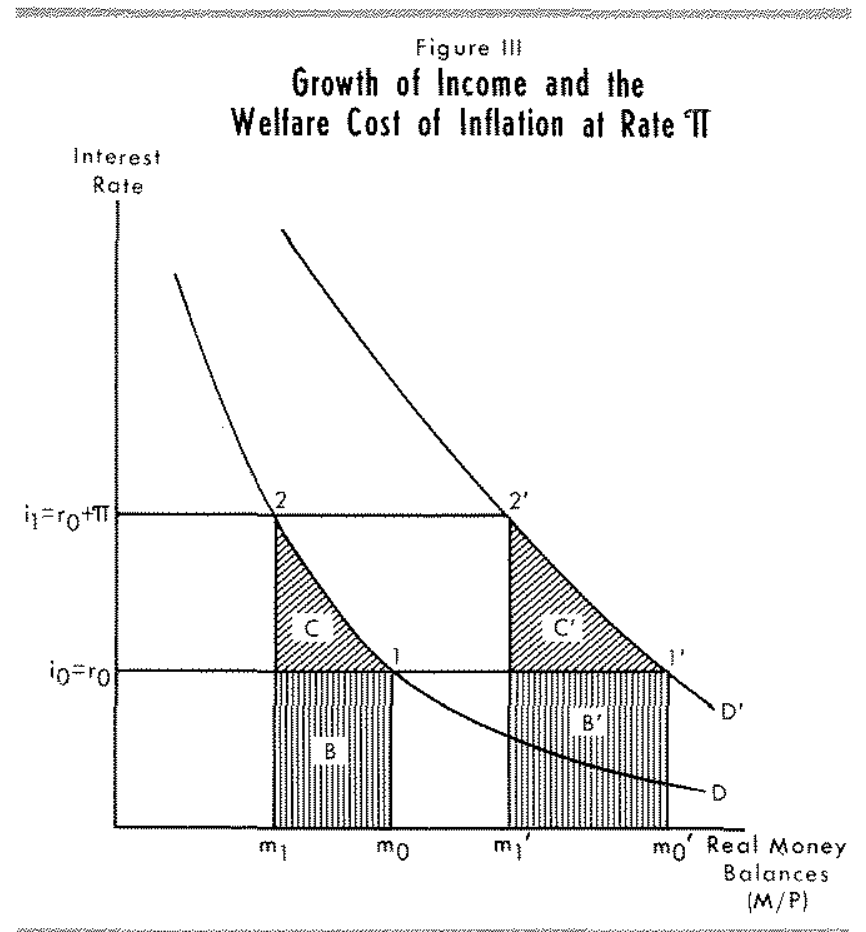

anticipated inflation, the annual welfare cost increases through time in a growing economy. It grows at the rate of growth of the demand for money. ${ }^{19}$ Therefore, the estimates of the annual welfare cost of anticipated inflation are again, understated, contrary to the position mentioned above.

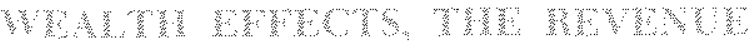

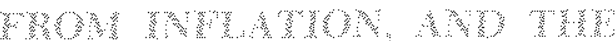

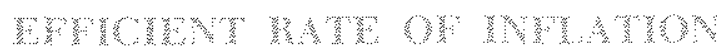

The analysis of the welfare cost of perfectly anticipated inflation in the last section is based upon an assumption of long-run adjustment to the anticipation. The analysis compares two equilibrium situations such as points 1 and 2 in Figure II. It ignores the adjustment process by which real money balances are reduced and any short-run cost which may be associated with the transition. This assumption appears to be critical in light of the theoretical results arising from the recent rediscovery of wealth effects on economic behavior. The anticipation of inflation will not leave "other things equal" along the demand for

\footnotetext{
19The analysis here, following the empirical literature, assumes that the interest rate and anticipated inflation rate elasticities of demand for money are unaffected by the level of other determinants of demand such as the level of income.

It may be noted in Figure III that at the given rate of inflation, $\pi$, the supply of real money balances, $\mathrm{m}_{1}$, grows at the rate of growth of demand. Therefore, the equivalerst of area $A$ in Fignere II also grows at this rate.
}

money curve in Figure II. In the short-run the analysis of the welfare cost of inflation must either account for shifts in the demand curve or for other changes which are necessary to keep the demand curve in its original position. The latter method is pursued here. A policy of implementing a permanent rate of inflation is described below which obviates the shift in the demand curve. This policy also clarifies the effect of inflation on the government's budget.

Given a level of nominal money balances, a change in anticipations to a higher rate of expected inflation will reduce real money balances through a one-time change in the general level of prices. The price level must be sufficiently higher to eliminate the excess supply of real money balances. This is illustrated in Figure IV, Panel A. The reduction in real money balances demanded, from point 1 to point 2 will create an excess supply of real money balances, given the initial price level, $P$. The corresponding excess demand for other real goods and services will result in a one-time surge in prices to $P_{1}$. This rise in the level of prices eliminates the excess supply of real cash balances at point 2 .

The analysis of the previous section has two implicit assumptions. The first is a technical point. The welfare cost analyzed there is not the cost associated with moving along a price path such as $\mathrm{P}_{0} \mathrm{AP}$ in Figure $\mathrm{V}$. Instead, the level of prices will surge upward when the rate of money growth rises from zero to $\rho=\pi$. Thus, the price path associated with the nominal money supply path $M$ in Figure $V$ will be $P_{0} A B P^{\prime}$, where time to is the point when the rate of money growth rises.

The second implicit assumption is more serious. The analysis above ignores wealth effects. In particular, the surge in prices to level $P_{1}$ will reduce the real value of net monetary assets in household portfolios. The analysis assumes that this short-run reduction in real wealth has no effect on the demand for real cash balances and other goods and services.

The initial reduction in real wealth due to a price surge will cause households to attempt to restore their lost wealth. Thus, households reduce their spending on goods and services and their desired holdings of real cash balances. Since part of the excess demand for goods and services is eliminated due to the wealth reduction, the price surge will be smaller when wealth effects are included. Also, the increased saving rate of households to restore wealth will reduce the real rate of return on physical capital. Thus, the 

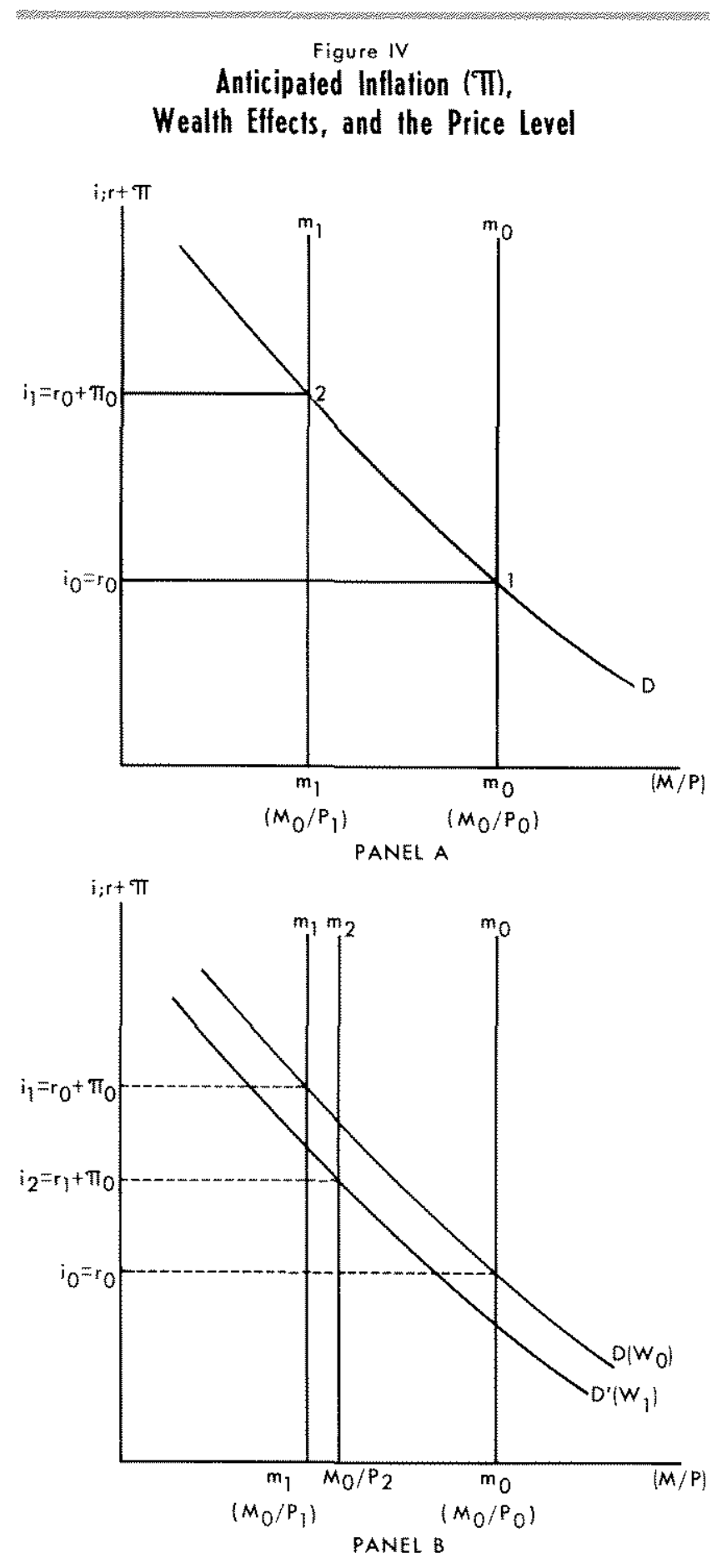

nominal rate will not increase by the rate of anticipated inflation.

The ultimate effects on the analysis are shown in Figure IV, Panel B. The demand for real money balances will shift to the left due to the smaller level of wealth $\left(W_{1}\right)$ with price level $P_{2}$. Also the nominal interest rate will be higher and reflect the rate of inflation $\pi_{0}$, but at interest rate $i_{2}$ instead of $i_{1}$. The real rate of interest is lower, $r_{1}$. The earlier analysis is complicated by short-run changes in two of its parameters: the decline in the real rate of interest, and the smaller level of real wealth.

The cost of moving along a price path such as PoAP in Figure $V$, allowing for the short-run effects of the reduction in desired real balances, may be found in a policy context which removes these analytical complications. The reduction in desired cash balances can be facilitated by a one-time accommodating monetary policy, rather than the one-time surge in the price level. An open market sale of bonds in exchange for the excess cash balances, $\left(m_{0}-m_{1}\right)$ in Panel $B$, will leave wealth unaffected. ${ }^{20}$ The real money supply falls to $m_{1}$ via a decline in the nominal money supply rather than a higher price level. Wealth, the price level, and the real rate of interest will be unchanged. Since these are the major determinants of the demand for money, other than the expected rate of inflation, there will be no shift in the demand for money. The increase in the rate of monetary growth requires an open market sale of bonds initially to, in effect, "soak up" the excess real cash balances which it initially causes. ${ }^{21}$ Furthermore, to avoid a wealth effect in the future from the rising price level, net financial wealth, the money stock plus the value of debt held by the public, must grow at the same rate as prices.

The revenue from inflationary finance may also be more clearly seen in such a conceptual framework. The open market sale of government bonds by the central bank increases the real value of government debt held by the public. From the government's viewpoint, the revenue effect of the inflation includes the additional revenue of the central bank $\left(\pi \mathrm{m}_{1}\right)$ less the real interest payment on the increase in public debt. Since the increase in the public debt equals the permanent desired reduction in real money balances due to the inflation expectation, the revenue of inflation in Figure $I I$ is the area $A$ less area B $\left[\mathrm{r}_{0}\left(\mathrm{~m}_{3}-\mathrm{m}_{1}\right)\right]$.

20The relevant real wealth variable includes real money balances, the real value of government debt, and the real value of capital.

*The effects of inflationary expectations on the price level and real rate of interest have also been noted by Cathcart, "Monetary Dynamics," and Leonardo Auernheimer, "The Honest Government's Guide to the Revenue from the Creation of Money," Journal of Political Economy (May/June 1974), pp. 598-606. Auernheimer also pointed out the importance of the initial open market sales prior to a higher rate of monetary expansion to avoid the one-time price surge. 


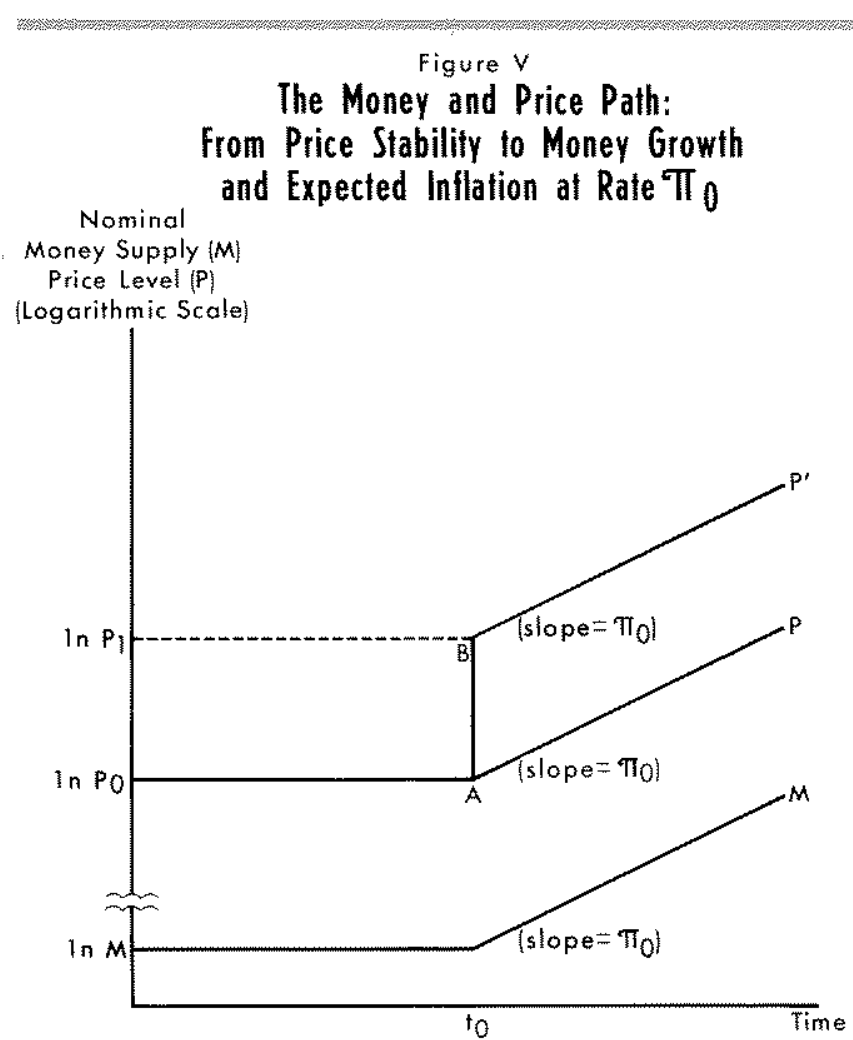

The subtraction of area $B$ from the revenue of inflation also affects the earlier analysis of the cost of inflation. Area $B$ remains part of the real value of lost money services per period. In addition, it represents the increase in the real value of interest payments per period due to the larger public held debt. Therefore, the gross burden or total cost is $(A+C)$.

The analysis in the previous section is little affected by dropping the long-run perspective. Both the revenue and the total burden of inflation are reduced by the size of area $B$. The revenue $(A)$ is reduced to account for the increased interest payments required on the larger public debt. The total burden $(\mathrm{A}+\mathrm{B}$ $+C$ ) is reduced because of the receipt by households of larger annual interest payments on the public debt represented by area $B$. Hence, the excess burden or welfare cost remains the same, area $(B+C)$ in Figure II.

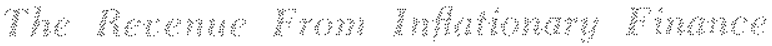

The size of the revenue from inflation depends on the elasticity of demand for real money balances with respect to the expected rate of inflation. The area $A$ in Figure II is the rate of inflation times the level of real money balances, about $\$ 300$ billion measured in current dollars, or, with a 5 percent rate of expected inflation, $\$ 15$ billion. The area $B$ in Figure II depends upon the size of the reduction in real money balances due to a 5 percent rate of inflation and upon the level of the real rate of return on assets, the nominal interest rate in the absence of inflation. Employing the earlier estimate of an elasticity of demand of .15 , and either of the two estimates of the real rate of interest ( 2 percent or 5 percent), the area of rectangle $B$ is $\$ 2.25$ billion. The area $(A-B)$ for a 5 percent rate of inflation is $\$ 12.75$ billion, in current dollars."2

The measure of revenue as the area $A$ less area $B$ is subject to an additional important qualification. Not all of the money stock is provided through the monetary authority. In fact the stock of money supplied by the monetary authority, the monetary base, is less than forty percent of the stock of money. The relationship between the monetary base and the money supply is remarkably stable, so the government's share of the total stock of money may be defined as (sm) where $s$ is the ratio of the monetary base to the money supply.

The base for government revenue from money creation is not the total money supply, but only the monetary base. Therefore, the revenue area $(A-B)$ above must be multiplied by $s$ to present an accurate estimate of the government revenue from inflationary finance.: With an estimate of $s$ of 40 percent, the government revenue from a 5 percent rate of inflation is approximately $\$ 5.1$ billion $(.4 \times \$ 12.75$ billion $)$.

In contrast, the Federal revenues in $1975^{\circ}$ from the corporate income tax and personal income tax were $\$ 42.6$ billion and $\$ 125.7$ billion, respectively. A rate of inflation of 5 percent appears to be a very costly method to raise a modest amount of Federal revenue. The welfare cost per dollar of revenue raised from a monetary policy which yields a 5 percent actual and expected rate of inflation, using the cost and revenue figures above, is 80 to 120 cents per dollar of government income. The welfare costs per dollar of revenue from the personal income tax and

WIn a growing ecomomy, the annual revenue from money creation is litger since even price stability regures that the supply of nominal money frow at the rate of growth of denand for real noney batances. This larger revenue grows at the rate of growth of money demand and the welfare cost. See footnote 19 above.

$2:$ The remainder of the revenue (A-B) accrues, through the banking system, to bank owners and, through competition, to their depositors. The welfate cost analysis above is not affected by relaxing the assumption that all money is supplied by the monetary authority. The cost of holding bank money rises in the same mannes as it does for currency. 
the corporate income tax in 1975 were on the order of three cents per dollar of revenue.

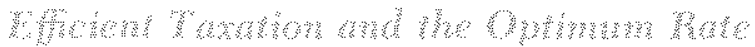
of ritherm

The relevant measure of cost for an efficient tax system is the marginal cost per dollar of additional revenue, not the average cost. ${ }^{24}$ An efficient tax system raises a given total revenue from various taxes with a minimum total cost. Therefore, for each tax, the cost per dollar of revenue must be equated at the margin. It is difficult to reach definitive conclusions concerning the optimum rate of monetary expansion and inflation without knowledge of the marginal cost of alternative revenue sources. Unfortunately, this cost for all alternative taxes has not been estimated. Nevertheless, an upper bound on the size of such marginal costs has been placed at 10 cents per dollar of government receipt and this may be used here. ${ }^{25}$

The marginal welfare cost of inflationary finance may be written as:

$$
c=\left(\frac{e^{2}}{1-e^{x}}\right)\left(\frac{1}{s}\right) \quad 26
$$

Additional revenue is obtained from a higher rate of inflation only when the interest elasticity is less than one; if the interest elasticity rises with the rate of inflation, maximum revenue from inflition occurs when $e^{*}$ is equal to one. According to Equation (2), as $e^{*}$ approaches one, the marginal welfare cost approaches infinity. Also, Equation (2) indicates that the marginal cost is greater, the greater is the rate of inflation or interest elasticity of demand for money, and the smaller is the government's share of the money supply. Therefore, the estimates of an interest elasticity of .15 and share, $s$, of 40 percent, yield downward-biased estimates of the marginal welfare cost of government revenue from money expansion.

\footnotetext{
24kThis point has been emphasized by Alyin C. Marty, "A Note on the Welfare Cost of Money Creation, Journal of Monetary Economics (January 1976), pp. 121-24; and in Edward Tower, "More on the Welfare Cost of Inflationary Finance," Journal of Monet, Credit and Banking (November 1971), pp. 850 60; Catheart, "Monetary Dynamics:" Phelps, "Inflation;" Barro, "Inflationary Finance."

25See Tower, "More on the Welfare Cost," p. 856. The estimate of 10 percent is also consistent with the work of Edgar K. Browning, "The Marginal Cost of Public Funds" Journal of Political Economy (April 1976), p. 295. He estimates the marginal cost for the individual income tax, indeding administration and compliance costs, to be 9 percent in 1974

20The derivation of this equation is found in the Appendix as equation (8), where $e^{*}$ above is the interest rate elasticity of demand for real money balances, given the real rate of interest.
}

The marginal welfare cost in equation (2) is constant and equals 44 percent, given the estimates above. This level is well above the maximum estimate of the marginal welfare cost of alternative revenues above. Therefore, efficiency of the tax system does not warrant inflation or inflationary finance. Additional revenue, within the relevant range for the United States may be more cheaply obtained through other sources of revenue, not through inflation. ${ }^{2 T}$

\section{Mormushor}

In recent years, some economists have argued that there are benefits to inflation and, if the rate is stable and can be fully anticipated, there is little or no cost to society. The cost of perfectly anticipated inflation is its welfare cost. It results from the loss in welfare due to the substitution away from real money balances. While this cost may be small in relation to the costs of redistributions of income and wealth when inflation is unanticipated, it is comparable to the welfare costs of other major components of the U. S. tax system at levels of inflation as low as 5 percent. Moreover, the size of the welfare cost of inflation increases rapidly with the size of the rate of inflation itself. The welfare cost of inflation is independent of resource costs incurred to economize on cash balances; indeed, the analysis assumes these costs to be zero. To the extent that valuable resources are used to economize on cash holdings, the cost of perfectly anticipated inflation is even greater.

One of the primary benefits of inflation is the revenue it produces for the government. It has been suggested by some analysts that efficient taxation requires taxing cash balances through inflation. Indeed, since the demand for money is relatively insensitive to changes in the cost of holding money, high rates of inflation, appear to some to be justified on tax efficiency grounds. It has been shown here that tax efficiency can not justify a positive rate of inflation, even employing strong assumptions favoring the inflationist case.

The "tax efficiency argument" forces the question of the optimal rate of inflation into the domain of public finance. The answer depends upon the mar-

\footnotetext{
$\therefore$ A narginal welfare cost which is constant and above the marginal cost of alternative revenue actually stggests an efficient policy of deflation with revente losses for money creation beng replaced by additional revenue from alternalive taxes. However, it may be expected that the interest elasticity of demand for money is an increasing function of the rate of inflation. Therefore, the marginal welfare cost of revente from money creation will fall to the 10 percent level at a small rate of deflation.
} 
ginal costs of alternative revenue sources. While further research on the nature of other taxes is thereby required, the examination here supports some strong conclusions. Even if the marginal cost of alternative sources of revenue is much larger than the level suggested here as an upper bound, tax efficiency offers no support for inflationary public policy.

The efficiency of the tax system and the revenue potential of inflation appear to be insignificant arguments in the debate over the "optimum" rate of inflation. Such arguments have considerable theoretical appeal but, upon close examination, are of little practical importance. A positive rate of inflation is not supported by these arguments. Furthermore, the additional revenue obtained from a rate of inflation as high as 5 percent is small relative to the revenue obtained through money creation with price stability or relative to the revenue from alternative taxes. The practical importance of the "tax efficiency argument" is also limited by existing inefficiencies in the present tax system as well as the apparent difficulties of maintaining a steady and fully anticipated rate of inflation.

\section{The Efficient Taxation of Money}

A general derivation of the welfare cost, revenue, and marginal cost of inflationary finance may be found which is independent of the functional form of the demand for real money balances. The revente from money production is:

(1) $\mathrm{R}=\mathrm{s}$ i $\mathrm{m}$

where $s$ is the ratio of the monetary base to money and is assumed to be constant. The effect on revenue of a change in the rate of inflation is:

(2) $\frac{\mathrm{dR}}{\mathrm{d} \pi}=\sin \left(1+\frac{\mathrm{i}}{\mathrm{m}} \frac{\partial \mathrm{m}}{\partial \mathrm{m}}\right)$.

Let the demand for real money balances be written as a function of the expected rate of inflation, $\phi(\pi)$. The welfare cost of inflation is:

(3) $W=\int_{0}^{\pi} \phi(x) d x-i \phi(\pi)+r \phi(0)$

The effect of an increase in the expected rate of inflation is:

(4) $\frac{d W}{d \pi}=-i \phi^{7}$

It is assumed here, as in the text, that the real rate of retum is unaffected by the expectation of inflation or that a one percentage point rise in the expected rate of inflation adds one percentage point to the nominal interest rate.
The marginal cost of inflationary finance, $c$, is:

(5) $c \cdot \frac{d W}{d R}=\frac{d W}{d n} / \frac{d R}{d r}=\frac{-i \phi^{\prime}}{\left(m+i \phi^{\prime}\right) \mathrm{s}}$

The elasticity of demand for money with respect to the nominal rate of interest, given the real rate of interest, and with respect to the expected rate of inflation are defined as:
(6) $E_{i}=-\frac{a m}{\partial i} \frac{i}{m}=-\frac{\partial m}{\partial n} \frac{i}{m}-\phi^{\prime} \frac{i}{m}$ and
(7) $\mathrm{E}_{\mathrm{r}}=-\frac{\partial \mathrm{m}}{\partial \pi} \frac{\mathrm{r}}{\mathrm{m}}-\phi_{\mathrm{m}}^{\mathrm{E}} \frac{\pi}{\mathrm{m}}$

Then the marginal cost, $c$, may be written altenatively as:

(s) $c=\frac{i E_{\Pi}}{s\left(n-i E_{\pi}\right)}=\frac{E_{i}}{s\left(l-E_{i}\right)}$

In the usual analysis of the welfare cost of inflation a special functional form is employed in which the elasticity of demand for money with respect to the expected rate of inflation is an increasing function of the expected rate of inflation. In particular, it is written as:

(9) $\mathrm{E}_{\pi}=\mathrm{b}$

where $b$ is a constant. For this case, the earlier equations become: 
(2) $\frac{d R}{d n}=s m(1-i b)$

(4') $\frac{d W}{d t}=b m i$

(5) $t=\frac{\mathrm{dW}}{\mathrm{dR}}=\frac{\mathrm{bi}}{(1-\mathrm{ib}) \mathrm{s}}$

Since the elasticity of demand for money increases with the rate of inflation, the demand will become elastic with respect to either the rate of inflation or the nominal inter. est rate at a sufficiently high rate of inflation. Therefore, there is a rate of inflation which maximizes revenue, a higher rate of inflation yields lower revenue from money production. This maximum rate of inflation ( $\pi_{\text {max }}$ ) may be found by letting $\frac{d R}{d \pi}$ equal zero in equation (2').

(10) $r_{\max }=\frac{1}{b}-r_{0}$

The marginal cost in $\left(5^{\prime}\right)$ is infmite at this rate of infiation.

The size of the revenue maximizing rate of inflation depends upon the value of $b$ and the real rate of interest, $r$. The precise level of $b$ for the United States is unknown, although some evidence exists on the appropriate number. A level of 2 is probably far too low and may serve as a lower bound. Estimates ranging up to 78 have been made for the U. S. Some illustrative values which have been cited are; 2,10 , and 20 years. ${ }^{2}$ Together with the alternative real rates of interest in the text, the revenue maximizing annual rate of inflation is found to vary from

"See Milton Friedman, "Government Revenue from Inflation," Journal of Political Economy (July/August 1971), pp. 851-53. zero to 48 percent with the mid-range, 5 to 8 percent, for $b=10$. The rate of inflation warranted by an efficient tax system will be substantially less than the revenue maximizing rate.

The marginal welfare cost of revenue from money creation is larger, according to equation $\left(5^{\prime}\right)$, the larger is $b$, the real rate of interest, or the expected rate of infla tion. The marginal cost, $c$, is zero when the nominal interest rate is zero, that is, when the expected rate of deflation equals the real rate of return on capital. The marginal welfare cost of revenue with price stability may be found from equation $\left(5^{\prime}\right)$ by letting the nominal rate equal the real rate of interest.

Using the levels of $b$ above and the two levels of the real rate of interest, 5 percent or 2 percent, the marginal welfare cost ranges from 10 percent to infinity, for $\pi=0$. In the smallest case ( 10 percent), the level of $b$ is 2 years, and $r$ is 2 percent, i.e. the interest rate elasticity of demand $(\mathrm{rb})$ is only .04 , much less than the elasticity generally observed. Moreover, this minimum level of the marginal welfare cost with price stability is equal to the maximum estimate of the alternative marginal cost cited in the text. Therefore, under the most extreme assumptions used here to support inflationary finance, efficient taxation warrants price stability. Even if the altemative marginal cost is doubled to 20 percent, the warranted rate of inflation with these assumptions is only about 1.5 percent. For more reasonable assumptions concerning $b$ and $r$, efficient taxation would warant defiation.

The "tax efficiency" argument may not be used to justify high rates of inflation. In fact, this argument suggests that the warranted rate is negative, but less in magnitude than the real rate of interest. 